\title{
POLITITIKK
}

\section{Altid beredt! Den danske ekspeditionsparathed i komparativt lys}

\author{
Hans Mouritzen \\ Dansk Institut for Internationale Studier (DIIS), Danmark
}

\begin{abstract}
Sammenfatning
Komparation med sammenlignelige lande negligeres som oftest i studier af dansk militær 'aktivisme'. Dette bidrag vil bøde på det i en analyse af Danmarks interventionsparathed med Norge og Polen som baggrundstæppe. Den konkrete situation, der studeres, er krisen vedr. begrænsede luftangreb mod Syrien i september 2013 i kølvandet på regimets formodede anvendelse af kemiske våben i Ghouta. I modsætning til de fleste allierede lod Danmark sig ikke afskrække af den kontroversielle Irak-intervention 10 år tidligere. Danmarks særlige parathed handlede mindre om lokale omstændigheder end om Danmark selv, forholdet til Washington og landets angivelige historiske 'gæld' til USA. Det er imidlertid svært at måle en sådan gæld, ligesom det er en udfordring for superatlantismen, at Danmarks interesser er mere geografisk begrænsede end stormagten USAs.
\end{abstract}

Nøgleord: Danmark • historiske analogier • Norge • Polen • Syrienkrisen 2013

\section{Indledning}

Danmark er altid parat til at gå i krig - ikke på egen hånd, men hvis en større allieret magt beder om dansk deltagelse. Og mere end det: hvis det blot anticiperes i løbet af en krisesituation, at en forespørgsel - typisk amerikansk - er på vej, signaleres villighed til at deltage (forudsat naturligvis at de danske kapabiliteter er relevante). På det

\footnotetext{
^Kontaktinformasjon: Hans Mouritzen, e-post: hmo@diis.dk

(C)2020 Hans Mouritzen. This is an Open Access article distributed under the terms of the Creative Commons Attribution 4.0 International License (http://creativecommons.org/licenses/by/4.0/), allowing third parties to copy and redistribute the material in any medium or format and to remix, transform, and build upon the material for any purpose, even commercially, provided the original work is properly cited and states its license.

Citation: Mouritzen, H. (2020). Altid beredt! Den danske ekspeditionsparathed i komparativt lys. Internasjonal Politikk, 78(3), 421-432. http://dx.doi.org/10.23865/intpol.v78.2497
} 
operative niveau foregår sideløbende en forberedelse for alle eventualiteter, således at indsættelse vil kunne ske hurtigt efter en politisk beslutning. Danske styrker er 'happy both to travel and to fight' (Jakobsen \& Rynning, 2019). Dette mønster, hvis konturer har været velkendte, er grundigt dokumenteret i en udredning fra 2019 (Mariager \& Wivel, 2019a, 2019b). Den omhandler dansk militær indsættelse mod Serbien 1999 (Kosovokonflikten), i Afghanistan fra 2001 og i Irak fra 2003. Formentlig har det samme mønster gentaget sig i forbindelse med Libyen-indsatsen $\mathrm{i}$ 2011.

Jeg skal her belyse Danmarks parathed i forhold til en, i sidste øjeblik, aborteret aktion: begrænsede bombardementer mod syriske mål i kølvandet på regimets formodede anvendelse af kemiske våben i Ghouta (Damaskus) i august 2013. Den danske parathed vil blive analyseret med Polen og Norge som komparativt baggrundstæppe. Analyser af mindre NATO-landes profiler inddrager, udover landet selv, ofte kun USA og den eventuelle 'slagmark'. Ikke mindst i dansk debat mangler komparation med sammenlignelige allierede og dermed refleksion over, hvorfor de ofte handler forskelligt overfor de samme udfordringer. ${ }^{1}$ I det aktuelle tilfælde var Danmark interventionsparat og indtog herved en særstilling i forhold til sammenlignelige lande. Hvad skyldtes det?

Et svar på dette spørgsmål vil blive søgt. Paratheden handler ikke - som man naivt skulle tro - om de aktuelle begivenheder i Syrien eller Mellemøsten, men om Danmark selv og dets forhold til primært USA. Skarpt sat op: af mangel på presserende aktuelle trusler anno 2013 lod Danmark sig, som i tidligere situationer, motivere af 'gammel gæld' til USA. Polen med sin historiske offerrolle mente derimod ikke at skylde nogen noget; tværtimod burde andre engagere sig i Polens angiveligt udsatte position i forhold til Rusland. Norge befriet fra såvel skyld- som offerkomplekser og alvorlige trusler anno 2013 henholdt sig til sin kompromisløse FN-samvittighed, ifølge hvilken væbnet aktion ville kræve vedtagelse i Sikkerhedsrådet. $\mathrm{Og}$ en sådan var der ikke udsigt til.

\section{Syrienkrisen 20I3: det store billede}

Ifølge amerikanske, britiske og franske efterretningskilder var al-Assad-styret ansvarligt for et storstilet angreb mod civile med kemiske våben i Ghouta d. 21. august 2013, hvilket dog blev benægtet af styret selv og dets russiske allierede. Rusland og Kina, der følte sig svigtet af Vesten vedr. Libyen i 2011, angav at ville blokere for en fordømmelse i FNs Sikkerhedsråd. De følgende dage forberedte USA, UK og Frankrig et begrænset bombardement af mål i Syrien, medens Tyrkiet ønskede en

\footnotetext{
${ }^{1}$ Jf. f.eks. den i øvrigt nyttige antologi 'Danmark i krig' (Søby Kristensen, 2013). Den indeholder elleve kapitler om forskellige aspekter af dansk krigsførelse, men ikke en eneste komparation med sammenlignelige lande. Som hæderlige undtagelser fra den nævnte tendens kan fremhæves Jakobsen, Ringsmose \& Saxi (2018) samt Petersson \& Saxi (2013).
} 
større aktion. Tyskland appellerede til FNs Sikkerhedsråd om at nå til enighed, men udelukkede $i$ alle tilfælde egen deltagelse $i$ et militært indgreb.

Til manges overraskelse fik premierminister Camerons planer om britisk deltagelse i et begrænset angreb på Syrien flertal imod sig i Underhuset (29. august). Ligeså overraskende erklærede USAs præsident Obama d. 31. august, at nok havde han besluttet sig for et begrænset angreb, men det skulle først blåstemples i Kongressen. Den omstændelige proces i Kongressen, der nu kunne forudses, gav spillerum for diplomatiet. I forbindelse med G-20 topmødet i St. Petersborg drøftede Obama og Ruslands præsident Putin muligheden for at få Syrien til at afgive sine store lagre af kemiske våben, hvorved behovet for en militær indsats ville bortfalde. Via en efterfølgende amerikansk-russisk diplomatisk proces, hvorunder Ruslands udenrigsminister Lavrov lagde pres på Syrien, lykkedes det at opnå syrisk tilslutning til at afgive sine lagre (Verdens Gang, 2013a). Aftalen blev implementeret via multinationale styrker og $\mathrm{OPCW}^{2}$ i løbet af vinteren og foråret 2014. Syrien tilkendegav at ville tilslutte sig 'Chemical Weapons Convention'.

\section{Den danske positionering}

Der var to faser i den danske beslutningsproces. Indtil 27. august henholdt den danske regering (centrum-venstre: S-SF-RV) sig til FN-sporet og håbet om en fælles beslutning i Sikkerhedsrådet. Som udtrykt af statsminister Thorning-Schmidt: 'fra dansk side har vi hele tiden lagt vægt på at følge FN-sporet. Det har altid store konsekvenser at gribe ind uden et FN-mandat' (Fyens Stiftstidende, 2013). Udenrigsminister Søvndal slog endda en polemisk tone an mod de borgerlige partier (V og K): "jeg [vil] minde de to partier om det kaos, som de har været med til at skabe i Irak, fordi de valgte at lade Danmark deltage i en krig uden international legitimitet" (Berlingske 23. august 2013). Søvndal beskrev det på dette tidspunkt som realistisk at opnå enighed i FNs Sikkerhedsråd, hvis blot FNs våbeninspektører kunne fremskaffe de nødvendige beviser.

Skønt vælgerne var skeptiske over for dansk militær deltagelse uden FN-mandat, ${ }^{3}$ skiftede statsministeren signaler fra 27. august: "hvis FN's Sikkerhedsråd ikke vil reagere i den nuværende situation, så er vi nødt til at overveje alternative reaktionsmønstre" (Politiken, 2013a). Og udenrigsministeren fulgte efter: "Hvis Sikkerhedsrådet ikke er i stand til det, så rykker alternative scenarier hurtigt nærmere. Det må vi også i Danmark forholde os til” (Jydske Vestkysten, 2013).

På Udenrigspolitisk Nævns møde d. 29. august fik regeringen opbakning til en evt. deltagelse $\mathrm{i}$ en militær aktion. "Jeg har tilkendegivet overfor vore nærmeste allierede, og USA ved dette, at hvis FN-sporet ender blindt, vil Danmark være rede til at

\footnotetext{
${ }^{2}$ Organisation for the Prohibition of Chemical Weapons.

${ }^{3}$ Ifølge Gallup var $64 \%$ af vælgerne 'uenige' eller 'delvis uenige' i dansk deltagelse uden FN-mandat (Berlingske 27. august 2013). 23\% var enige.
} 
overveje alternative handlemuligheder", udtalte statsministeren efter mødet (Ritzau 29. august 2013). Men 'Danmark er ikke blevet bedt om at bidrage til en militær indsats', tilføjede hun i samme åndedrag.

Afstemningen samme aften i det britiske Underhus, som satte en stopper for britisk militær deltagelse, kom bag på de danske politikere. "Jeg er overrasket over, at det britiske parlament ikke bakker op om sin egen premierminister", udtalte formanden for Udenrigspolitisk Nævn Mette Gjerskov (Politiken.dk 30. august 2013). Men hun tilføjede, at Danmark træffer sin egen beslutning om en evt. militær indgriben i konflikten (Politiken, 2013b). Ifølge udenrigsminister Søvndal stillede den britiske beslutning Danmark overfor et virkeligt dilemma, som gav anledning til eftertanke (TV2 News 30. august 2013). Men vi må også overveje, hed det videre, hvordan vi kan komme en desperat syrisk befolkning til undsætning.

Forsvarsminister Wammen holdt stadig døren åben for dansk militær deltagelse uden de nære britiske partnere og uden FN-mandat. Han var overbevist om det syriske regimes brug af kemiske våben. "Kerry selv [USAs udenrigsminister, 30. august] lagde stor vægt på, at netop erfaringerne fra Irak gør, at man har været ekstra forsigtige fra amerikansk side i forhold til de oplysninger, USA har fremlagt," svarede Wammen en journalist, der havde henvist til USAs udenrigsminister Powell's 'beviser' i 2003 i FNs Sikkerhedsråd vedr. eksistensen af masseødelæggelsesvåben i Irak (Information.dk 30. august 2013). Gjerskov havde den samme tillid til amerikanske efterretninger: "jeg noterer, at amerikanerne er rimeligt sikre på, hvad de siger... beviserne vil formentlig komme snarest."4

Obama mødtes med de fem nordiske statsministre i et længe planlagt møde i Stockholm 4.-5. september, umiddelbart før hans deltagelse i G-20 mødet i St. Petersborg. Her stod Thorning-Schmidt alene blandt sine nordiske kolleger med opbakningen til en evt. amerikansk militær indgriben (stadig med mulig dansk deltagelse, omend det igen blev understreget, at hun ikke var blevet bedt om en sådan; Aftenposten, 2013).

Det er således tydeligt, at der ikke hvilede nogen afskrækkende 'Irak-skygge' over den danske beslutningsproces. Interventionen i Irak 20. marts 2003, som Danmark deltog i, var uden et klart FN-mandat og baseret på, som det skulle vise sig, falske CIA-efterretninger (om end regeringens krigsbegrundelse ikke direkte henviste hertil). ${ }^{5} \mathrm{FN}$ blev kun betonet de første par dage af Syrienkrisen, som vi så. Og logikken i Wammen-citatet, som også andre danske politikere bød ind på, var lidt paradoksal: 'netop fordi de snød os sidste gang, kan vi være sikre på, at det ikke sker igen' [forf. formulering]. Det er i øvrigt bemærkelsesværdigt i forløbet, at

\footnotetext{
${ }^{4}$ Politiken 28. August 2013 ('Danskerne skal lige vænne sig til tanken om at gå uden om FN').

${ }^{5}$ Formålet med Danmarks krigsdeltagelse var at bidrage til at 'gennemtvinge irakisk efterlevelse af landets nedrustningsforpligtelser i henhold til FNs resolutioner.' Det nævntes dog, at dette ville være i overensstemmelse med 'den danske ikke-spredningspolitik i relation til masseødelæggelsesvåben.' Se Retsinformation, 2003.
} 
danske politikere konsekvent svarer på det hypotetiske spørgsmål om, hvordan man vil reagere på en evt. kommende amerikansk anmodning om deltagelse; politikere er som bekendt trænede i generelt at undgå at besvare hypotetiske spørgsmål. Ergo er det, fordi det i situationen skønnedes vitalt at signalere den danske parathed. Danmark kom i øvrigt senere til at indtage en hovedrolle i den multinationale maritime transportoperation til bortskaffelse af de kemiske våbenarsenaler (Brems Knudsen 2014). ${ }^{6}$ Også dette var et udslag af parathed.

\section{De polske og norske NATO-partnere}

Som allerede nævnt reagerede Danmarks nabo-allierede, Polen og Norge, ganske anderledes. Men grundene var vidt forskellige i Warszawa og Oslo.

Polen lagde utvetydigt afstand til tanken om en militær indsats mod Syrien. Med henvisning til Polens tidligere bidrag til Irak-interventionen havde landet 'erfaringer fra denne del af verden [Mellemøsten i bredere forstand], som viser, at militær intervention, selv med de mest oplagte og noble motiver, sjældent leverer de ønskede effekter' (premierminister Donald Tusk 28. august 2013; Radio Poland).

Kort forinden var den såkaldte 'Komorowski-doktrin' blevet formuleret af præsidenten (15. august, dvs. før gasangrebet i Damaskus): "vi vil afgjort afskaffe den overambitiøse ekspeditionspolitik, som vi uforsigtigt startede i 2007. Polske tropper vil ikke længere i huj og hast blive sendt ud til verdens brændpunkter" (Daily News 16. august 2013, nr. 159/2013). I stedet betonede præsident Komorowski vigtigheden af polsk territorialforsvar. Både præsidentens og premierministerens udtalelser skal bl.a. ses på baggrund af en markant mangel på folkelig opbakning til udenlandske operationer (CPF, 2016). ${ }^{7}$

Polens sikkerhedspolitiske fokus efter den Kolde Krig har været begrænset til dets umiddelbare naboskab, dvs. den russiske 'arvefjende'. Polske engagementer andetsteds er derfor blevet set som nødtvungen 'betaling' for amerikansk (NATO-) afskrækkelse af Rusland - m.a.o. quid pro quo. Polakkerne følte imidlertid ikke, at den ydede afskrækkelse var tilstrækkelig; med den russiske Georgien-intervention i 2008 og større russiske øvelser mod vest (Zapad) ønskede Polen ikke kun flere og større NATO-øvelser på sit territorium, men også permanent stationering af NATO-styrker (CPF, 2016). Men tidligere 'halve løfter' herom i forbindelse med Irak-interventionen i 2003 var forblevet uopfyldt. Polsk skuffelse over Obamaadministrationens nedjustering af det planlagte missilforsvar i Polen i marts 2013 kan også have spillet en rolle (New York Times, 2013). Generelt følte man ikke, at der blev lyttet tilstrækkeligt til polske synspunkter i Washington (CPF, 2016).

\footnotetext{
${ }^{6}$ Der var en vis dansk-norsk rivalisering om den overordnede kommando op til operationens start, jf. Olesen, 2017, s. 362.

${ }^{7}$ Polen havde også sendt styrker til Afghanistan, men afstod fra deltagelse i Libyen-bombningerne.
} 
Norges statsminister Jens Stoltenberg udtalte støtte til FNs generalsekretær Ban $\mathrm{Ki}-\mathrm{moon}$, som i en telefonsamtale med Stoltenberg 28. august havde betonet, at 'vi er nødt til at give diplomatiet og FN-inspektørerne en chance. Fakta må på bordet' (BT, 2013). Stoltenberg afviste ikke bare norsk deltagelse i en militæraktion mod Syrien uden FN-mandat, men udtrykte også bekymring over visse allieredes planer om at angribe mål i Syrien uden opbakning fra FN.

Omtrent samtidig udviklede den norske udenrigsminister Eide sammen med sin svenske kollega Bildt idéen om at isolere konflikten til en fordømmelse af kemiske våben, uanset hvem der måtte have brugt dem (Verdens Gang, 2013b). I Eides formulering er det 'at blive enige [i FNs Sikkerhedsråd] om at gribe ind i Syrien nu...vanskeligt, men det er mindre krævende at blive enige om en fordømmelse af kemiske våben' (Verdens Gang, 2016). Syrien skulle tilslutte sig 'Chemical Weapons Convention', og dets lagre måtte bringes under international kontrol. Idéen blev testet positiv i forhold til Lavrov, og forslaget vandt støtte på et nordisk udenrigsministermøde i Visby 30. august. Det blev dernæst drøftet med Obama på topmødet i Stockholm 4.-5. september, og herefter fulgte den nævnte russisk-amerikanske diplomatiske proces.

\section{Irak preller af på Danmark - men hvorfor?}

Politiske ledere tager deres beslutninger i lys af aktuelle overvejelser - her situationen i og omkring Syrien og deres egen geopolitiske stilling - men ofte i samspil med en bestemt historisk analogi. ${ }^{8}$ Analogien her refererede, som allerede nævnt, til interventionen i Irak i marts 2003. Situationen omkring Syrien havde flere ligheder med forspillet til invasionen i Irak: et mellemøstligt diktatur beskyldes, baseret på primært amerikanske efterretningskilder, for at besidde eller anvende masseødelæggelsesvåben. FNs våbeninspektører er i gang med at undersøge spørgsmålet lokalt, men der forventes et veto fra FNs Sikkerhedsråd mod militær indgriben. Irak-erfaringen er generelt $\mathrm{i}$ eftertiden blevet stemplet som en fiasko: masseødelæggelsesvåben blev ikke fundet, ${ }^{9}$ og det demokratiske eksperiment i landet har været medvirkende til en langvarig borgerkrig og anselige tabstal hos de fremmede styrker. Erfaringen kastede en skygge over præsident Bushs anden embedsperiode, og UK premierminister Tony Blairs eftermæle tog alvorligt skade.

På denne baggrund er det ikke den store overraskelse, at Irak-interventionen var et af hovedargumenterne mod et - ganske vist langt mere begrænset - Syrien-indgreb i debatterne i både Storbritannien og USA. Et ofte hørt argument var 'mission creep': at en i udgangspunktet begrænset indsats ville udvikle sig til et betydeligt større og længerevarende engagement. At beslutningstagere og parlamentarikere reagerer modsat en tidligere 'analog' beslutning, med rette eller urette stemplet som

\footnotetext{
${ }^{8}$ Se f.eks. en dansk case i Mouritzen \& Olesen (2010).

${ }^{9}$ Se Jervis (2006) om efterretningsfiaskoen.
} 
en fiasko, er hyppigt forekommende i udenrigspolitik (en udenrigspolitisk 'lektie'). ${ }^{10}$ Men sådan var det ikke i Danmark, har vi allerede set, når der bortses fra de første par dage (indtil 27. august). ${ }^{11}$ Tilliden til amerikanske efterretninger var usvækket, FN-argumentet forsvandt og briternes afbud viste sig uden synderlig betydning. Danmark var parat og indtog herved en særstilling i forhold til sammenlignelige lande. Hvad skyldes det?

Der er umiddelbart ingen grund til at tro, at danske politikere skulle være mindre modtagelige for Irak-argumentet end andre landes politikere. Svaret er formentlig, at deres succeskriterium er et andet: det er ikke koalitionens samlede indsats, det drejer sig om, men derimod kvaliteten af Danmarks egen indsats, herunder om den blev værdsat i specielt Washington. Hovedfejlene, der blev begået før og under Irak-indsatsen, var ikke danske fejl. Som led i en småstatstankegang fralægger politikere og kommentatorer sig ansvar for den substantielle helhed (Lidegaard, 2018) - det må lederne af koalitionen tage på sig. ${ }^{12}$ Et andet eksempel kunne være Libyen-bombningerne 2011, hvor man lidt ondskabsfuldt kunne hævde, at 'operationen lykkedes, men patienten døde.' Men den danske indsats var en politisk og operativ succes. ${ }^{13}$

Denne tolkning understøttes af den nævnte danske udredning fra 2019 (Mariager \& Wivel, 2019a), som har påvist en betydelig kontinuitet i beslutningsprocesserne op til deltagelsen i Serbien-, Afghanistan- og Irakkrigene. I den offentlige retorik betonedes forhindringen af humanitære katastrofer eller sikringen af den internationale retsorden og demokratiet i det relevante land. Men bag facaden - især i Statsministeriet, hvor de afgørende beslutninger blev truffet - var det forholdet til Washington, der var afgørende. ${ }^{14}$ Bemærkelsesværdigt nok var overvejelser vedr. substansen i den konkrete konflikt - det være sig i Serbien, Afghanistan eller Irak - af mindre betydning (jf. også Lidegaard, 2018). Vigtig har i alle tilfælde været Danmarks genvundne militære selvrespekt, specielt efter 'Operation Bøllebank' (Bosnien, 1994), og præcedensen fra

\footnotetext{
${ }^{10}$ Der foreligger en omfattende international litteratur om dette. Se f.eks. henvisninger i Mouritzen (2020).

${ }^{11}$ Som en yderligere indikation kan nævnes, at Fogh Rasmussens personlige karriere - modsat Tony Blairs - ikke tog skade af Irak-erfaringen, måske tværtimod. Fogh Rasmussen var den statsminister (V), der besluttede, at Danmark skulle deltage i intervention i Irak i marts 2003 uden klart FN-mandat.

${ }^{12}$ F.eks. opløsningen af det irakiske militær eller fyringen af embedsmænd tilhørende Baath-partiet, som skabte grobund for opstanden mod de fremmede styrker.

${ }^{13}$ Jakobsen \& Møller (2012) taler om 'the perfect war' i forhold til danske interesser. Det nævnes iøvrigt af Jakobsen \& Rynning (2019), at Danmark fældede hele 11 pct. af NATOs totale antal bomber (923 stk. 'smart ammunition').

${ }^{14}$ Se kilderne fra Statsministeriet vedr. f.eks. beslutningen i september 1998 om deltagelse i en evt. krig vedr. Kosovo (ss. 69-78 i bind 4, Mariager \& Wivel, 2019a). Ikke-deltagelse ville betyde, at 'Danmarks status og indflydelse i NATO med et slag vil være sat over styr', og det ville 'reducere Danmarks generelle udenrigspolitiske gennemslagskraft mange år frem i tiden.' Bl.a. ville Danmarks muligheder for at hjælpe balterne ind i NATO og EU blive formindsket.
} 
Danmarks deltagelse i Serbienkrigen 1999 uden FN-mandat - humanitær intervention under ledelse af en socialdemokratisk statsminister (Mariager \& Wivel, 2019b).

Henvisningerne til FN-sporet de første par dage af Syrienkrisen skyldtes formentlig, at statsministeren endnu ikke havde kendskab til de allieredes reaktion. Men det vides, at hun d. 27. august havde telefonkontakter med Cameron, Frankrigs præsident Hollande og Tyrkiets premierminister Erdogan, og formentlig havde hun set den amerikanske udenrigsminister Kerrys markante TV-tale aftenen i forvejen (Jydske Vestkysten 27. august 2013). Disse inputs gjorde tydeligvis indtryk. Statsministeren betonede nu vigtigheden af at 'vi lytter til, hvad vores nærmeste allierede siger i denne sag. Og det er briterne, franskmændene og amerikanerne. ${ }^{15} \mathrm{Og}$ videre: 'Det ligger i direkte forlængelse af ikke bare den socialdemokratiske, men også den danske udenrigspolitik gennem rigtig mange år, at vi så tydeligt bakker op om vores allierede.'

Det havde hun ret i. Udtalelserne antyder, at hun har internaliseret Fogh Rasmussens 'superatlantisme' med basis i hans normative 'anti-småstatslektie' fra 2002-03 (Mellander \& Mouritzen, 2016, ss. 457-459): Danmark skal hæve stemmen i verden, også værdipolitisk, og undertiden deltage i amerikansk ledede militære operationer langt fra de danske kyster. Dette som en modsætning til tidligere tiders 'usle' småstatsadfærd, herunder 'sejlen under bekvemmelighedsflag' i NATO under den Kolde Krig. ${ }^{16}$ Fogh Rasmussens kritik retter sig mod tilpasningspolitikken til Tyskland fra ca. 1870 til 1918, 1935 til 1940 og - tydeligst - under den tyske fredsbesættelse af Danmark fra 9. april 1940 frem til 29. august 1943. Men også mod alliancepolitikken i NATO hvor Danmark med sin 'lave profil' afviste fremmede styrker såvel som atomvåben på dansk jord. 'Danmarkisering' i NATO-jargon i 1980'erne betød et medlemsland, der ikke ville spendere tilstrækkeligt på sit forsvarsbudget. Hertil kom det danske Folketingsflertals modvilje mod amerikanske mellemdistanceraketter i Vesteuropa, udmøntet i de såkaldte 'fodnoter' i NATO kommunikéer.

Irak-lektien preller således af på Danmark, fordi danske beslutningstagere i forvejen mere eller mindre har internaliseret Fogh Rasmussens grundlæggende anti-småstatslektie. Den handler om Danmark selv (en art selvterapi) og hvad landet angiveligt skylder Washington af historiske grunde. Paradokset er så, at netop ansvarsfralæggelsen i forhold til substansen og helheden i interventionerne er udtryk for en småstatstankegang.

\section{Danmark skylder, Polen har til gode, mens Norge har ro i sindet}

Som Danmark uddrager Polen en lektie af historien, men den stik modsatte. Polen skylder ikke nogen noget, tværtimod. Ikke mindst den nuværende ledelse trækker

\footnotetext{
${ }^{15}$ Politiken 4. september 2013. Bemærk i øvrigt, at Tyskland ikke bliver nævnt; formentlig har der ikke været kontakt med kansler Merkel, der havde en anden opfattelse end Thorning-Schmidt.

${ }^{16}$ Se f.eks. Fogh Rasmussens kommentar i Berlingske 26. marts 2003.
} 
ofte offerkortet, både i forhold til de tyske og russiske naboer. Engagementer udenfor egen interessesfære kan til nød finde sted, men er så betaling for en øget amerikansk (NATO-) afskrækkelse af Rusland, som er det geopolitisk aksiomatiske. Bliver forventningen herom skuffet, falder der ingen ydelse næste gang. Polen har tilstrækkelig selvtillid til som 'kreditor' og mellemstor magt at blive fornærmet over manglende lydhørhed i Washington. ${ }^{17}$

Norge mener historisk hverken at skylde eller være offer. Norge havde under 2. verdenskrig en eksilregering i London og kom ud af krigen uden skam; på den anden side var man heller ikke en svigtet offernation som polakkerne. Norge har heller ikke som Danmark haft en giftig og opslidende skylddebat om sin rolle i NATO under den Kolde Krig. ${ }^{18}$ Derfor kan Norge koncentrere sig om nutiden. Dette overskud er én blandt andre grunde til en universalistisk og kompromisløs FN-linje (jf. også statsminister Bondeviks afvisning af Irak-interventionen, selv under pres fra USA; Mouritzen, 2006, især ss. 155-156). Det var karakteristisk i 2013-krisen, at Stoltenberg talte i telefon med FNs generalsekretær og blev bestyrket i sin opfattelse af, hvor uheldig militær intervention ville være uden $\mathrm{FN}$-mandat. Stoltenberg begrænsede sig i øvrigt ikke til at redegøre for Norges egen stilling, men kritiserede også allieredes interventionsforberedelser, endda offentligt som vi har set.

Modsat Stoltenberg førte Thorning-Schmidt telefonsamtaler med de mest interventionspositive alliancepartnere. Det er karakteristisk efter den Kolde Krig, at Danmark i tilfælde af konkurrerende FN- og USA-hensyn i sikkerhedspolitikken har prioriteret USA, ${ }^{19}$ hvilket også er sket ved interne uenigheder i NATO. Da Danmark ikke længere var frontlinjestat som under den Kolde Krig, betød bortfaldet af geopolitiske afspændingshensyn, at der nu var overskud til at betale af på 'gammel gæld'. Deltagelse (under amerikansk ledelse) blev et mål i sig selv, og det var derfor vigtigt altid at vise sig beredt. Materielanskaffelser er selvsagt tilpasset ekspeditionsønsket, og paratheden er også gennem ca. 30 år blevet internaliseret på det operative plan, i medierne og blandt forskere under kodeordet 'aktivisme'. I den forstand er den danske parathed blevet 'selvkørende', så man ikke i hvert enkelt tilfælde behøver at reflektere over de dybereliggende incitamenter (som oprindelig - og skarpest - blev formuleret af Fogh Rasmussen).

En række alternative forklaringer virker mindre sandsynlige. Partipolitik har ingen forklaringskraft.Vi ser f.eks., hvordan en tidligere kritiker af Irak-interventionen, udenrigsminister Villy Søvndal (SF), blev omvendt i processens forløb. Donald Tusk (Borgerforum), der langt fra tilhører den nationale del af det polske politiske

\footnotetext{
${ }^{17}$ Under Trump-administrationen har Polen dog nydt godt af betydeligt større lydhørhed end under Obama-administrationen.

${ }^{18}$ Debatten har splittet det danske historikermiljø. Se Farbøl, 2017.

${ }^{19}$ Næsten profetisk står der i regeringsprogrammet fra 2011: "Intervention for at beskytte civilbefolkningen skal som altovervejende hovedregel foretages på grundlag af et mandat fra FNs Sikkerhedsråd. Men hvis Sikkerhedsrådet er ude af stand til at handle...kan det være nødvendigt undtagelsesvis, at Danmark deltager...”. Se iøvrigt Andersen, 2019.
} 
spektrum, valgte alligevel en markant national linje. Vælgeropinionen kan ligeledes afskrives: selv i Danmark var der flertal mod politikernes parathed.

En indvending mod gældsfortolkningen kunne være, at motivationen snarere handlede om fremtiden: amerikansk beskyttelse ved et fremtidigt angreb på Danmark ('fear of abandonment', Snyder, 1998). Men med dette argument skulle jo Norge og Polen, i noget mere udsatte positioner, være mindst lige så parate. Komparationen svækker denne forklaring.

En alternativ (eller supplerende) fortolkning kunne være, at deltagelsen i ekspeditioner prestigemæssigt i NATO evt. kan kompensere for lavere forsvarsbudgetter, jf. Jacobsen og Rynning (2019). Men med den logik skulle jo også Norge have været parat. Det skal desuden huskes, at den amerikanske kritik af europæernes forsvarsbudgetter var betydeligt mere urban i 2013 end idag.

Komparation er selvsagt ikke de 'vises sten'. Enhver samfundsvidenskabsstuderende lærer om komparationens fordele på det første metodologiske kursus. Men den kan afgørende gennemhulle forskellige vaneforestillinger fra den nationale kontekst. Og måske også rette opmærksomheden mod en valid forklaring.

Den danske internalisering af 'afbetalingsstrategien' er tilsyneladende så stærk, at den kan opveje forskellige medfølgende ulemper. En af disse er, at det er umuligt at måle gælden, herunder vide hvornår den er betalt. En anden ulempe er, at beslutningstagerne kan blive fristet til at give køb på danske egeninteresser, som selvsagt er langt mere geografisk begrænsede end supermagtens. En tredje vanskelighed er pendulsvingninger ${ }^{20}$ og vibrationer i USAs sikkerhedspolitik. Ikke mindst Trumpadministrationens volatile ledelse har været en udfordring.

\section{Om forfatteren}

Hans Mouritzen, dr.scient.pol., har udviklet teori om flere beslægtede emner: internationale organisationers autonomi, småstatspolitik og dens rumlige forudsætninger, hvordan ekstern fare påvirker internt sammenhold, og hvordan historisk erindring indvirker på nutidens udenrigspolitiske beslutninger ('fortidens skygge').

\section{Referencer}

Aftenposten. (2013). Stoltenberg etter middagen: Obama er utålmodig. Hentet 15. oktober 2020 fra https:// www.aftenposten.no/verden/i/zG551/Stoltenberg-etter-middagen-Obama-er-utalmodig

Andersen, L. (2019). The UN - a forgotten cornerstone in Danish foreign policy. Danish Foreign Policy Review, 2019, 99-131.

Brems Knudsen, T. (2014). Danish contributions in Syria and Mali: Active internationalism in a changing world order. I Danish Foreign Policy Yearbook 2014 (s. 76-109). København: DIIS.

BT. (2013). Stoltenberg udelukker norsk krigsdeltagelse i Syrien uden FN-mandat. Hentet 15. oktober 2020 fra https://www.bt.dk/udland/stoltenberg-udelukker-norsk-krigsdeltagelse-i-syrien-uden-fn-mandat

\footnotetext{
${ }^{20}$ Typisk ved skifte af administration. Danske diplomater har fremhævet deres særlige access i Washington (State Department eller Pentagon) som et resultat af strategien (Henriksen \& Ringsmose, 2011). Denne fordel blev imidlertid stort set elimineret med præsidentskiftet i 2017.
} 
CPF. (2016). New strategy in the fight against ISIS - what role for Poland? Hentet 15. oktober 2020 fra https:// pulaski.pl/en/new-strategy-in-the-fight-against-isis-what-role-for-poland/

Farbøl, R. (2017). Koldkrigere, medløbere og røde lejesvende. Kampen om historien. København: Gads forlag.

Fyens Stiftstidende. (2013). Thorning: Militær indsats i Syrien er stadig hypotetisk. Hentet 15. oktober 2020 fra https://fyens.dk/artikel/thorning-milit\%C3\%A6r-indsats-i-syrien-er-stadig-hypotetisk

Henriksen, A. \& Ringsmose, J. (2011). Hvad fik Danmark ud af det? Irak, Afghanistan og forholdet til Washington. DIIS Report 2011:14. København: DIIS.

Jakobsen, P. V. \& Møller, K. J. (2012). Good News: Libya and the Danish Way of War. I Danish Foreign Policy Yearbook 2012 (s. 106-131). København: DIIS.

Jakobsen, P. V., Ringsmose, J., \& Saxi, H. L. (2018). Prestige-seeking small states: Danish and Norwegian military contributions to US-led operations. European journal of international security, 3(2), 256-277.

Jakobsen, P.V. \& Rynning, S. (2019). Denmark: Happy to fight, will travel. International Affairs, 95(4), 877-895.

Jervis, R. (2006). Reports, politics, and intelligence failures: The case of Iraq. The fournal of Strategic Studies, 29(1), 3-52.

Jydske Vestkysten. (2013). Søvndal: Syrisk giftangreb er voldsom optrapning. Hentet 15. oktober 2020 fra https://jv.dk/artikel/søvndal-syrisk-giftangreb-er-voldsom-optrapning-2013-8-27(3)

Lidegaard, B. (2018). Danmark $i$ krig. Aarhus: Aarhus Universitetsforlag.

Mariager, R. \& Wivel, A. (2019a). Hvorfor gik Danmark $i$ krig? Uvildig udredning af baggrunden for Danmarks militcere engagement $i$ Kosovo, Afghanistan og Irak. Bd. 1-4. København.

Mariager, R. \& Wivel, A. (2019b). Denmark at war: great power politics and domestic action space in the cases of Kosovo, Afghanistan and Iraq. I Danish Foreign Policy Review 2019 (s. 48-73). København: DIIS.

Mellander, M. \& Mouritzen, H. (2016). Learning to assert themselves: Small states in asymmetrical dyads. Two Scandinavian dogs barking at the Russian bear. Cooperation and Conflict, 51(4), 447-67.

Mouritzen, H. (2006). Choosing sides in the European Iraq conflict: A test of new geopolitical theory. European Security, 15(2), 137-163.

Mouritzen, H. (2020). "Remember Iraq!" Learning theory and the 2013 non-decision on air strikes against Syria. International Politics. Hentet fra https://ink.springer.com/article/10.1057\%2Fs41311-020-00207-x

Mouritzen, H. \& Olesen, M. R. (2010). The interplay of geopolitics and historical lessons in foreign policy: Denmark facing German post-war Rearmament. Cooperation and Conflict, 45(4), 406-28.

New York Times. (2013). U.S. cancels part of missile defense that Russia opposed. Hentet 15. oktober 2020 fra https:/www.nytimes.com/2013/03/17/world/europe/with-eye-on-north-korea-us-cancels-missile-defenserussia-opposed.html

Olesen, M. R. (2017). Aktivismen med de nordiske "brødre": forsigtig spiren efter lang tids tørke? Politica, 49(4), 358-376.

Petersson, M. \& Saxi, H. L. (2013). Shifted roles: Explaining Danish and Norwegian alliance strategy 19492009. Journal of Strategic Studies, 36(6), 761-788.

Politiken. (2013a). Thorning vender på en tallerken om situationen i Syrien. Hentet 15. oktober 2020 fra https:/politiken.dk/udland/fokus_int/borgerkrigenisyrien/art5570991/Thorning-vender-p\%C3\%A5-entallerken-om-situationen-i-Syrien

Politiken. (2013b). S: Danmark træffer sin egen beslutning om krig i Syrien. Hentet 15. oktober 2020 fra https:/politiken.dk/udland/fokus_int/borgerkrigenisyrien/art5570983/S-Danmark-træffer-sin-egenbeslutning-om-krig-i-Syrien

Radio Poland. (2013). Poland will not join strikes on Syria. Hentet 15. oktober 2020 fra http://www.thenews. $\mathrm{pl} / 1 / 10 /$ Artykul/145573,Poland-will-not-join-strikes-on-Syria

Retsinformation. (2003). Skriftlig fremsættelse (18. marts 2003). 2002/1 SF. B 118. Hentet 15. oktober 2020 fra https://www.retsinformation.dk/eli/ft/20021XX00326

Snyder, G. (1998). Alliance Politics. Ithaca, NY: Cornell University Press.

Søby Kristensen, K. (Red.) (2013). Danmark $i$ krig. Demokrati, politik og strategi $i$ den militcere aktivisme. København: DJØF.

Verdens Gang. (2013a). Syriske opprørere avviser russisk forslag. Hentet 15. oktober 2020 fra https://www. vg.no/nyheter/utenriks/i/xLBvQ/syriske-opproerere-avviser-russisk-forslag

Verdens Gang. (2013b). Nordisk idé bak mulig Syria-løsning. Hentet 15. oktober 2020 fra https://www.vg.no/ nyheter/utenriks/i/bA12q/nordisk-ide-bak-mulig-syria-loesning

Verdens Gang. (2016). Stoltenberg om middagen med Obama: Et usedvanlig nyttig møte. Hentet 15. oktober 2020 fra https://www.vg.no/nyheter/utenriks/i/e3pwa/stoltenberg-om-middagen-med-obama-etusedvanlig-nyttig-moete 


\begin{abstract}
English
Always ready! Danish intervention enthusiasm in comparative perspective Comparison with similar countries is much neglected in studies of Danish military 'activism'. This contribution seeks to remedy that in an analysis of Danish forces' 'happiness both to travel and to fight', in which Norway and Poland serve as the comparative backcloth. The specific situation under scrutiny is the crisis over limited air raids over Syria in September 2013 in the wake of the regime's alleged use of chemical weapons in Ghouta. As distinct from most allies, Denmark was not discouraged by the controversial Iraq intervention 10 years earlier. The special Danish readiness was less about perceptions of the local conditions than about Denmark itself, its relationship to Washington and an alleged historical 'debt' to the US. However, not only is such debt difficult to measure; a challenge to superatlanticism is also that Danish interests are geographically more delimited than those of the US great power.
\end{abstract}

Keywords: Denmark • historical analogies • Norway • Poland • 2013 Syria crisis 